\title{
Article \\ Influence of the Silver Content on Mechanical Properties of Ti-Cu-Ag Thin Films
}

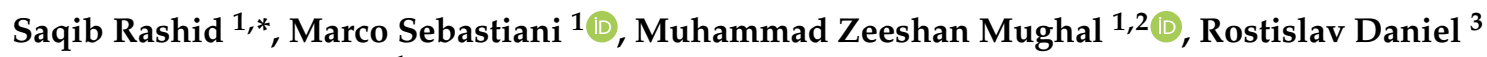 \\ and Edoardo Bemporad ${ }^{1}$ \\ 1 Engineering Department, University of Rome "Roma Tre", via della Vasca Navale 79, 00146 Rome, Italy; \\ marco.sebastiani@uniroma3.it (M.S.); zeeshan.mughal@open.ac.uk (M.Z.M.); \\ edoardo.bemporad@uniroma3.it (E.B.) \\ 2 School of Engineering \& Innovation, The Open University, Walton Hall, Milton Keynes MK7 6AA, UK \\ 3 Department of Materials Science, University of Leoben, Franz-Josef-Straße 18, 8700 Leoben, Austria; \\ rostislav.daniel@unileoben.ac.at \\ * Correspondence: saqib.rashid@uniroma3.it
}

Citation: Rashid, S.; Sebastiani, M.; Mughal, M.Z.; Daniel, R.; Bemporad, E. Influence of the Silver Content on Mechanical Properties of Ti-Cu-Ag Thin Films. Nanomaterials 2021, 11, 435. https://doi.org/10.3390/ nano11020435

Academic Editor: Imre Bakonyi

Received: 11 January 2021

Accepted: 5 February 2021

Published: 9 February 2021

Publisher's Note: MDPI stays neutral with regard to jurisdictional claims in published maps and institutional affiliations.
Keywords: Ti-Cu-Ag thin films; mechanical properties; magnetron sputtering; nanoindentation; FIB-DIC

\section{Introduction}

Over the years, metals have been widely used for biomedical implants because of their properties, such as mechanical strength, corrosion resistance, and biocompatibility $[1,2]$. Several metallic elements and their alloys such as titanium (Ti), Ti-based alloys, platinum $(\mathrm{Pt})$, and austenitic stainless steel $(316 \mathrm{~L})$ are used for orthopedic and biomedical applications [3]. However, degradation of metallic implant takes place due to the interaction with corrosive media inside the human body with a subsequent release of metallic ions, such as nickel (Ni) ions released from corrosion of titanium-nickel (Ti-Ni) alloy implants, which is harmful for the patients $[4,5]$. To solve the metallic degradation problem, surface treatment or application of thin films are common techniques used to improve the chemical, 
mechanical, and biological properties of the surface interfaced with the living tissues [6]. For biomedical implants, the most important factor is to have excellent corrosion resistance and low toxicity due to released metallic ions [7], possibly in combination with antibacterial or even antiviral functionalities [8,9].

Mostly monolayers or multilayers of oxides, nitrides, and carbides thin films of different elements such as $\mathrm{Zr}, \mathrm{Ti}, \mathrm{Cu}, \mathrm{Ni}, \mathrm{Au}$, and $\mathrm{Ag}$ are used in order to enhance the surface mechanical properties [10]. However, in order to further improve the corrosion resistance and biocompatibility of the implants, the implant alloys are often coated with various multi-element thin films such as $\mathrm{Zr}$-based thin films $(\mathrm{Zr}-\mathrm{Cu}, \mathrm{Zr}-\mathrm{Cu}-\mathrm{Ag}, \mathrm{ZrCN}$, $\mathrm{Zr} / \mathrm{ZrCN}$ multilayer) [11-13] and Ti-based thin films (TiN, Ti-Cu, Ti-Zr-Si) [14,15]. The Young's modulus and hardness of $\mathrm{Zr}$-based thin films were reported in the range of 95121.7 GPa and 5-7 GPa, respectively $[12,16]$. Ti-based thin films showed high hardness in the range of 5-12.5 GPa and elastic modulus of 90-200 GPa [17,18]. Metallic thin films have recently emerged as alternative advanced surfaces for many applications, such as micro/nano-electromechanical systems and for biomedical use. For instance, due to their structural features and physiochemical properties, interest is rising for metallic thin films in the field of bio-implants and surgical tools [19].

In particular, Ti-based intermetallic thin films could combine promising biocompatibility and high durability $[18,20]$. Among several available techniques, physical vapor deposition (PVD), e.g., sputtering, is one of the most commonly used techniques to coat implants [21], as the films produced by the sputtering process have very low surface roughness, which also play an important role on biofilm adhesion on Ti-based thin films [22-24]. The addition of several metallic elements during processing can improve the properties of pure Ti by the formation of intermetallic compounds. Specifically, silver (Ag) and copper $\mathrm{Cu}$ ) add new properties without showing a significant difference in biocompatibility [25]. The properties of intermetallic thin films are usually better than pure metallic films due to their mixed bonding (metallic, covalent, and ionic) at specific stoichiometry [26]. Many authors have studied the antibacterial behavior of metallic elements such as $\mathrm{Au}, \mathrm{Cu}, \mathrm{Zn}$, $\mathrm{Ag}$, and their alloys because of their ability to kill bacteria up to a broad spectrum [27]. The antibacterial mechanism of silver is complicated due to its interaction with thiol groups of bacteria proteins which may affect the replication of DNA [28]. However, various forms of Ag have been used in medicine in the past, including pure metal [29], silver nitrate [30], silver salts [29], silver polymer composite [8], silver nanoparticles [29,31], and Ag-based thin films [32].

In this framework, the study of the influence of $\mathrm{Ag}$ addition on the properties of Ti-based alloys still represents a major challenge in the scientific community. In fact, the improvement of antibacterial properties is usually accompanied by an undesired decay of the mechanical and tribological behavior, which needs to be solved. Although Ag has been used with $\mathrm{Zr}$-based thin films such as $\mathrm{Zr}-\mathrm{Cu}-\mathrm{Ag}$ in previous studies [33,34], to the best of the authors' knowledge, Ti-Cu-Ag thin films have never been used to coat biomedical implants, although there has been an increasing interest in application of Ti-Ag-based thin film systems in the biomedical field because of the two-fold advantage of this system: biocompatibility of titanium and antimicrobial effect of silver [32,35]. Copper is considered a promising element in the field of biomedical applications because of its antibacterial activity against numerous bacteria [36]. The biocidal performance of copper is associated to liberation of $\mathrm{Cu}^{+1}$ and $\mathrm{Cu}^{+2}$ ions [37-39] as observed in Ti-Cu [40].

In recent years, copper-based systems have also been proposed for the production of surface antiviral coatings with virucidal properties, especially in view of the recent COVID-19 pandemic [41,42]. Very recent examples include [42,43] copper-coated touch surface fabricated by cold-spray technology, as well as antiviral $\mathrm{Cu}_{x} \mathrm{O} / \mathrm{TiO}_{2}$ photo catalyst thin films with interesting photo-activated anti-viral properties.

These examples from the literature suggest the Ti-Cu-Ag system to be a promising ternary system for the production of surface with potential multiple biocidal functionality (both antibacterial and antiviral). At the same time, the analysis of feasibility for the real ap- 
plication of this ternary system requires a fundamental study on structure -microstructure -property correlation of the films, with specific focus on the mechanical properties that are a fundamental requirement for real industrial applications.

For this reason, in the present study we have produced and characterized $\mathrm{Ti}-\mathrm{Cu}-\mathrm{Ag}$ thin films with a varying $\mathrm{Ag}$ content from 10 to 35 at.\% on Si substrates by co-deposition of $\mathrm{Ti}, \mathrm{Cu}$, and $\mathrm{Ag}$ and studied thin films. The effect of the $\mathrm{Ag}$ content in the Ti-Cu-Ag composite thin films on their microstructure and mechanical properties is evaluated. Although the biocompatibility and antimicrobial and antibacterial properties are commonly the primary properties of interest of thin films for biomedical applications, we first focused on the correlation between the thin film composition and microstructure and their mechanical properties, which are as decisive for the application of thin films for implants as their antibacterial properties.

\section{Materials and Methods}

\subsection{Thin Film Deposition}

A series of Ti-Cu-Ag thin films was deposited on rotating $525 \mu$ m-thick silicon (100) substrates $\left(21 \times 7 \mathrm{~mm}^{2}\right)$ by direct current (DC) magnetron sputtering in a custom-made deposition system equipped with three unbalanced magnetrons. Three pure metallic targets, $\mathrm{Ti}, \mathrm{Cu}$, and $\mathrm{Ag}$ ( $3^{\prime \prime}$ in diameter), were employed with confocal arrangement at a maximum tilting angle of $\sim 50$ degrees with respect to the substrate normal (see Figure 1). The composite monolayer thin films were produced by the co-sputtering of all three targets at the same time at room temperature without applying negative substrate bias voltage. The power supplied to metallic targets to obtain the desired film compositions is summarized in Table 1. All the substrates were cleaned in ultrasonic bath and ethanol for $10 \mathrm{~min}$ before mounting on the substrate holder at equidistant positions with a Kapton polyimide tape. The distance between the substrates and targets was $70 \mathrm{~mm}$. The substrate rotation was kept constant at $80 \mathrm{rpm}$ for all thin films.
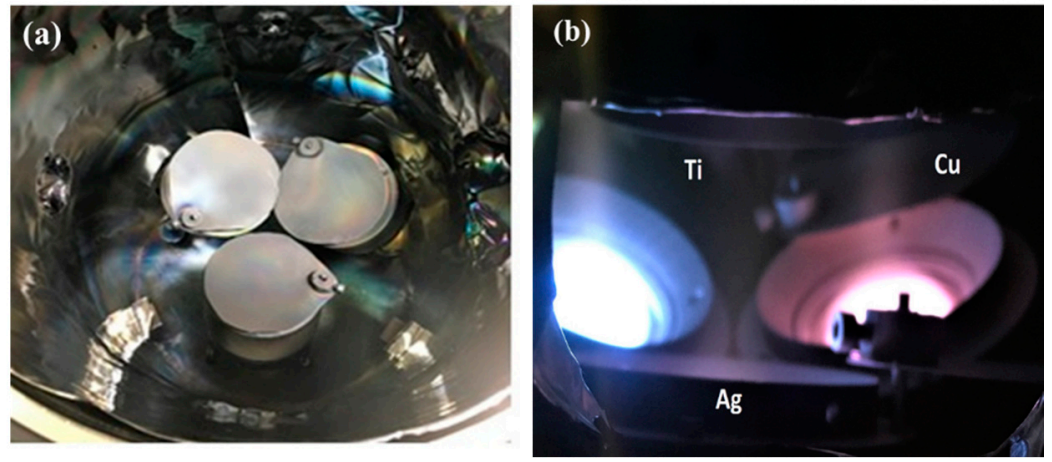

Figure 1. (a) Physical vapor deposition (PVD) chamber of three tilted metallic targets with respect to the substrate holder, and (b) targets ignite during sputtering.

Table 1. Power supplied to metallic targets to obtain the desired compositions.

\begin{tabular}{ccccc}
\hline Sample Composition & Ti:Cu $~ \mathbf{~}$ & $\begin{array}{c}\text { Power at Ti } \\
\text { (W) }\end{array}$ & $\begin{array}{c}\text { Power at Cu } \\
\text { (W) }\end{array}$ & $\begin{array}{c}\text { Power at Ag } \\
\text { (W) }\end{array}$ \\
\hline Ti-Cu (Control) & $48: 52$ & 150 & 29 & 0 \\
\hline Ti-Cu-10\%Ag & $43: 47$ & 143 & 27 & 3 \\
\hline Ti-Cu-15\%Ag & $40.5: 44.5$ & 135 & 26 & 4 \\
\hline Ti-Cu-20\%Ag & $38: 42$ & 128 & 24 & 5 \\
\hline Ti-Cu-25\%Ag & $35.5: 39.5$ & 120 & 23 & 7 \\
\hline Ti-Cu-30\%Ag & $33: 37$ & 113 & 21 & 9 \\
\hline Ti-Cu-35\%Ag & $30.75: 34.25$ & 105 & 20 & 11 \\
\hline
\end{tabular}


The deposition chamber was pumped down to a vacuum of approximately $1 \times 10^{-5} \mathrm{~Pa}$ before each deposition run. The argon pressure was maintained at $0.52 \mathrm{~Pa}$ corresponding to the gas flow of $30 \mathrm{sccm}$ for all thin films. For further substrate cleaning and surface activation, a preliminary etching step was performed, powered by radio frequency (RF) power supply at $50 \mathrm{KHz}$, at an argon pressure of $1.2 \mathrm{~Pa}$ and a discharge power of $0.03 \mathrm{KW}$. During the deposition, DC discharge power was applied to the magnetrons in a power-controlled mode for $40 \mathrm{~min}$ (see Table 1), resulting in film thickness varied between 1.40 and $1.48 \mu \mathrm{m}$, depending on the film composition.

\subsection{Characterization of Thin Films}

The crystallographic structure of the thin films was investigated by X-ray diffraction (XRD) using a $\theta-2 \theta$ Bruker D8 Advanced system with $\mathrm{Cu} \mathrm{K} \alpha$ radiation $(\lambda=0.154 \mathrm{~nm})$. Diffraction patterns were collected by using grazing incident angle of 1 degree with time step of $0.02^{\circ} / \mathrm{s}$. The operating voltage and current were $40 \mathrm{kV}$ and $40 \mathrm{~mA}$, respectively. The elemental composition of the thin films was evaluated via energy dispersive X-ray spectroscopy (EDX, Oxford Instrument INCA, High Wycombe, UK), using built-in sensitivity factors for calibration.

The film thicknesses were measured by using a white light optical profilometer with a Leica DCM 3D software package via automatic step measurement of coated and uncoated parts of the substrate. All the deposition rates were calculated as film thickness over the time, neglecting eventual differences in the film density. The surface topography and average roughness $R_{a}$ of the thin films were analyzed and measured using a Bruker atomic force microscope (AFM Dimension Icon, Bruker ${ }^{\circledR}$, Billerica, MA, USA) system scanning in a tapping mode with high aspect ratio tips according to the method described in our previous paper [44]. The tips used have half-apex angle of $<25^{\circ}$ with a spring constant of $42 \mathrm{~N} / \mathrm{m}$ and a resonant frequency of $320 \mathrm{KHz}$. All measurements were taken on an area of $5 \times 5 \mu^{2}$ and the data was processed using a Bruker Nanoscope Analysis software v1.40r1 suite.

Elastic modulus $(\mathrm{E})$ and hardness $(\mathrm{H})$, were determined using nano-indentation testing method, using a KLA-Nanomechanics G200, (KLA Corporation ${ }^{\circledR}$, Milpitas, CA, USA), fitted with a Berkovich diamond indenter operated in continuous stiffness measurement mode, hence allowing obtaining both $\mathbf{E}$ and $\mathbf{H}$, as a continuous function of the depth from a single indentation experiment [45]. A standard fused silica sample was tested before and after a batch of measurements to calibrate the tip and ensure the reliability of the results. For all measurements reported here, a minimum of 25 indentations were performed and the calculations were made by the Oliver and Pharr method from the load-displacement curve using $10 \%$ of the film thickness at the maximum indentation depth [46].

For adhesion evaluation, scratch tests were performed using an Anton Paar Revetest Xpress micro scratch tester (Anton Paar ${ }^{\circledR}$, Graz, Austria) in which critical load acting normal to the thin film surface at incident of failure is related to adhesion between thin film and substrate. However, critical load depends on mechanical strength (adhesion) of the thin film-substrate system but also on various parameters such as scratch indenter tip radius, film thickness, friction effects, hardness, and elastic modulus of coatings and substrate material. During the test, scratches were made on the surfaces with a spheroconical diamond tip (200 $\mu$ m radius) which is drawn at a constant speed $(16.5 \mathrm{~mm} / \mathrm{min})$ under a progressive load $(1-30 \mathrm{~N})$ with a fixed loading rate $(120 \mathrm{~N} / \mathrm{min})$.

\subsection{Residual Stress Measurements}

The residual stress measurements were carried out by the focused ion beam and digital image correlation (FIB-DIC) micro-ring core method on a FEI Helios Nanolab 600 dual beam focused ion beam scanning electron microscope (FIB/SEM, Thermo Fisher Scientific, Waltham, MA, USA), using a specifically developed automated procedure [47]. The milling was performed using an annular trench with an inner diameter of $6.5 \mu \mathrm{m}$ while employing a current of $0.92 \mathrm{nA}$ at the acceleration voltage of $30 \mathrm{kV}$. Ten high resolution secondary elec- 
tron images were acquired before and after each milling step using an integral of 128 images at a dwell time of $50 \mathrm{~ns}$. The automatic procedure continuously monitored and corrected electron and ion beam drift while maintaining the same contrast of the reference image. The milling was performed until the $h / D$ ratio of 0.2 was achieved, where $h$ and $D$ represent the milling depth and the pillar diameter, respectively. The $h / D$ ratio of 0.2 ensures an optimal strain relief, as demonstrated in number of recent publications [48-50]. After the milling cycle, all images were processed with a customized MATLAB v2.1.0.0 based DIC code [51] to calculate the relaxation strain over the pillar. Assuming an equi-biaxial stress distribution in the thin film, which is more than reasonable in the case of PVD films on flat substrates, average stress in the film was calculated by using the interpolated relaxation strain at $h / D=0.2$, elastic modulus $(E)$, and Poisson's ratio $(v)$ according to the following equation [52]:

$$
\sigma=-\frac{E \Delta \varepsilon}{(1-v)}
$$

where, $\sigma$ is the average residual stress in the film and $\Delta \varepsilon$ is the relaxation strain. Thin film thickness was also measured by using the FIB cross-section at a current of $0.92 \mathrm{nA}$ at $30 \mathrm{kV}$. The step-by-step milling procedure highlighting the different stages of milling process along with the thin film cross-section is represented in Figure 2.
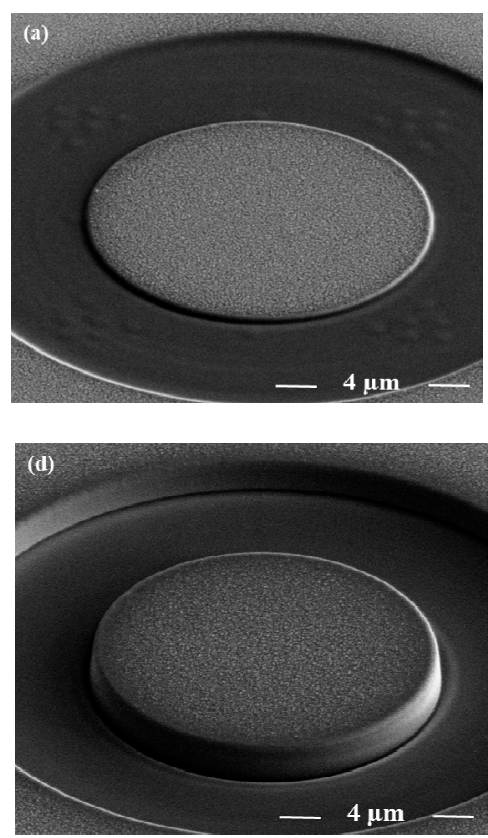
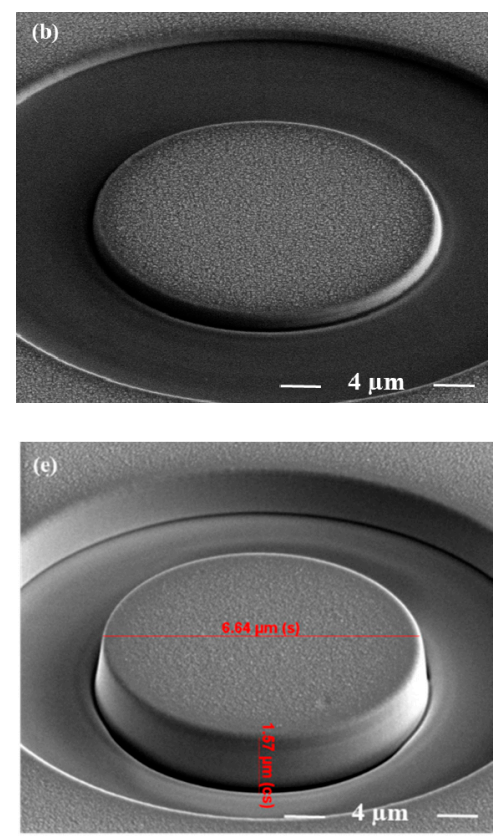
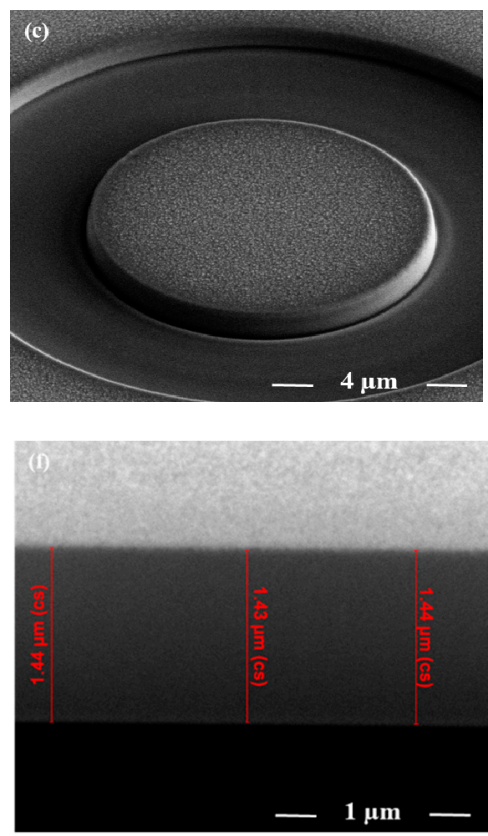

Figure 2. Representative images from (a-e) step-by-step milled pillar showing the semi-automatic milling procedure (scale bar only in figure (e)), and cross section (f), highlighting the thin film thickness.

The residual stress state was also indirectly determined by substrate curvature measurements, according to the Stoney's equation:

$$
\sigma_{f}=\left\{\frac{M_{s}}{6\left(1-v_{s}\right)}\right\}\left(\frac{t_{s}^{2}}{t_{f}}\right)\left(\frac{1}{R}-\frac{1}{R_{0}}\right)
$$

where $\sigma_{f}$ is the residual stress in the thin film, $t_{f}$ the film thickness, $t_{s}$ the substrate thickness, $M_{S}$ the biaxial elastic modulus of the substrate (180 GPa, in the present case), $v_{S}$ is the Poisson's ratio of the substrate, $R_{0}$ and $R$ are the radii of curvature of the substrate before and after the thin film deposition, respectively. 


\section{Results and Discussion}

\subsection{Elemental and Structural Characterization}

The Ti-Cu-Ag composite thin films with a varying Ag content were grown under optimized process conditions with regards to the target power and working pressure, while the $\mathrm{Ti} / \mathrm{Cu}$ ratio in the thin films was kept approximately equal to 1 by a slight variation of the target power, the $\mathrm{Ag}$ content was varied between 10 and 35 at. $\%$ by a progressive increase of power on the Ag target. The exact elemental composition from EDX measurements is shown in Table 1.

X-ray diffraction patterns of the as-deposited thin films are shown in Figure 3. For the binary Ti-Cu thin films, only a broad diffraction hump in the [38-45] 20-range is observed without any pronounced Bragg's diffraction peaks which represent amorphous glassy structure with Ti-Cu ratio nearly equal to one. Although the Ti-Cu alloys form multiple intermetallic compounds, a solid solution forms for alloys with the $\mathrm{Ti}_{48} \mathrm{Cu}_{52}$ composition [32]. This was the target composition of the Ti-Cu thin film in this study in order to get the amorphous bulk metallic glass structure [34]. While keeping the $\mathrm{Ti} / \mathrm{Cu}$ ratio constant and increasing the Ag content, the diffraction hump shifted towards lower $2 \theta$ angle. The position of the maximum level of broad peak can be correlated, in the first approximation, to the typical distance between nearest-neighbor atoms within the amorphous matrix. The decrease in the nearest neighbor distance with Ag content can be associated with the progressive substitution of $\mathrm{Ti}$ atoms by $\mathrm{Cu}$ and $\mathrm{Ag}$ atoms.

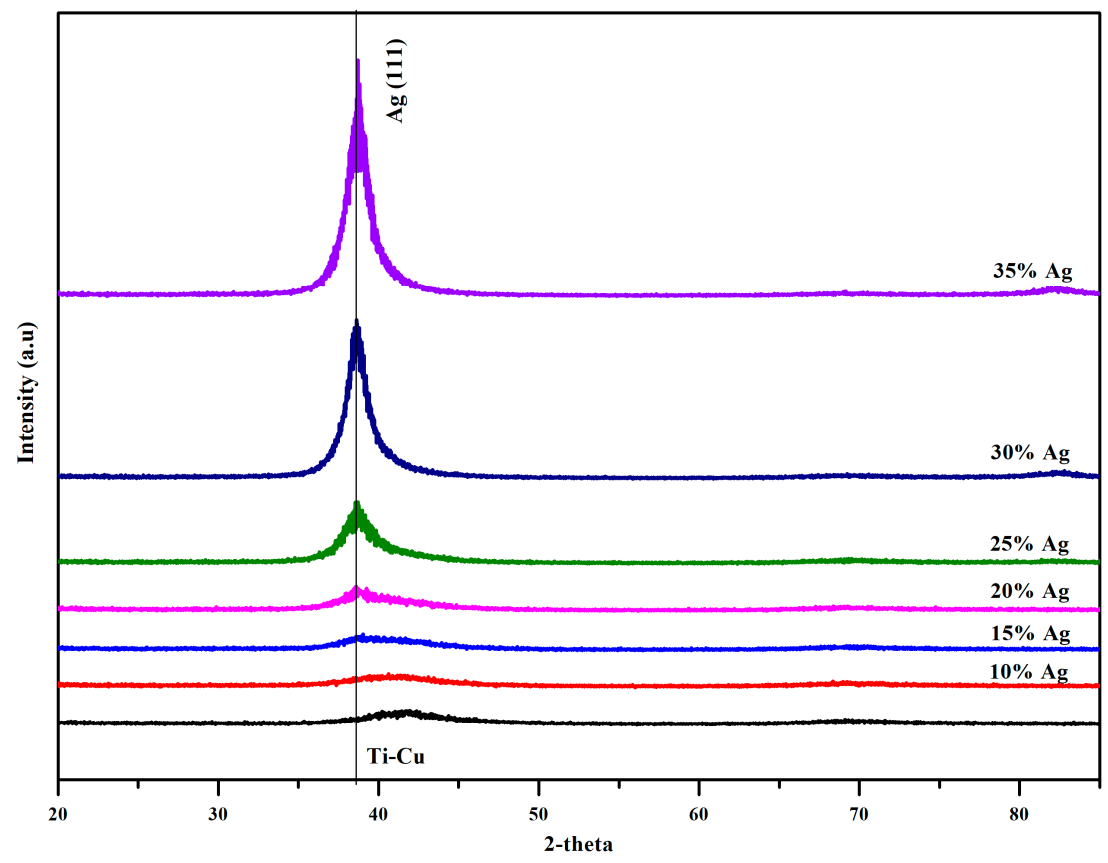

Figure 3. X-ray diffraction patterns of the Ti-Cu and $\mathrm{Ti}-\mathrm{Cu}-\mathrm{Ag}$ composite thin films on a silicon substrate with an Ag content varying between 10 and 35 at.\%.

While the structure of the Ti-Cu-Ag composite thin films with the Ag content lower than 25 at.\% remains amorphous similar to the binary Ti-Cu thin film (Figure 3), a more pronounced diffraction peak was observed for the ternary $\mathrm{Ti}-\mathrm{Cu}-\mathrm{Ag}$ thin films with the Ag content varying from 25 to 35 at.\% reflecting their nanocrystalline structure. The full width at half maximum (FWHM) of the diffraction peak is obviously higher for the binary Ti-Cu thin films than for the composite Ti-Cu-Ag thin films and decreased when the Ag content increased. This feature may reflect a more ordered structure of the $\mathrm{Ti}-\mathrm{Cu}-\mathrm{Ag}$ thin films than that of the Ti-Cu thin films especially for the Ag contents higher than 25 at.\%. Therefore, the Ag content of $\sim 25$ at. $\%$ was identified as a critical threshold for the transition from an amorphous to a crystalline structure of Ti-Cu-Ag system. 


\subsection{Surface Morphology}

The surface average roughness $\mathrm{R}_{\mathrm{a}}$ of the Ti-Cu-Ag thin films with a varying $\mathrm{Ag}$ content determined by AFM is shown in Figure 4. The AFM images reveal crack-free smooth surfaces for all thin films with an increase in roughness as the Ag content increases from 10 to 35 at. $\%$.
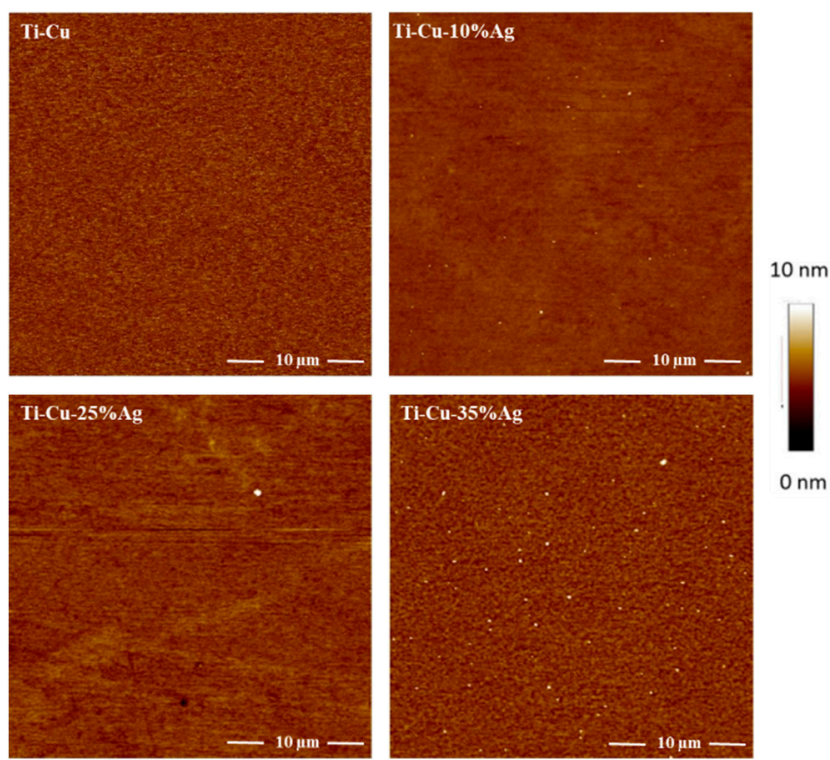

Figure 4. Atomic force microscope (AFM) images of the Ti-Cu and Ti-Cu-Ag thin films with 10, 25, and 35 at. $\%$ of $\mathrm{Ag}$.

The surface roughness increase from 0.5 to $1.3 \mathrm{~nm}$ corresponds to the appearance of the crystalline phase at the Ag content of $\sim 20$ at.\% and grain coarsening at higher Ag content of 35 at.\% (Figure 4). On the other hand, the amorphous Ti-Cu thin film and Ti-Cu-Ag thin films with the $\mathrm{Ag}$ content below 20 at.\% exhibit the average surface roughness well below $0.5 \mathrm{~nm}$ (Figure 5). Thin films with such a low average surface roughness are in general very favorable for antibacterial biomedical applications [8], especially if an adequate amount of antimicrobial agents such as $\mathrm{Ag}$ and $\mathrm{Cu}$ is added into the protective thin films, which induce a release of metallic ions after exposure to a humid environment [53].

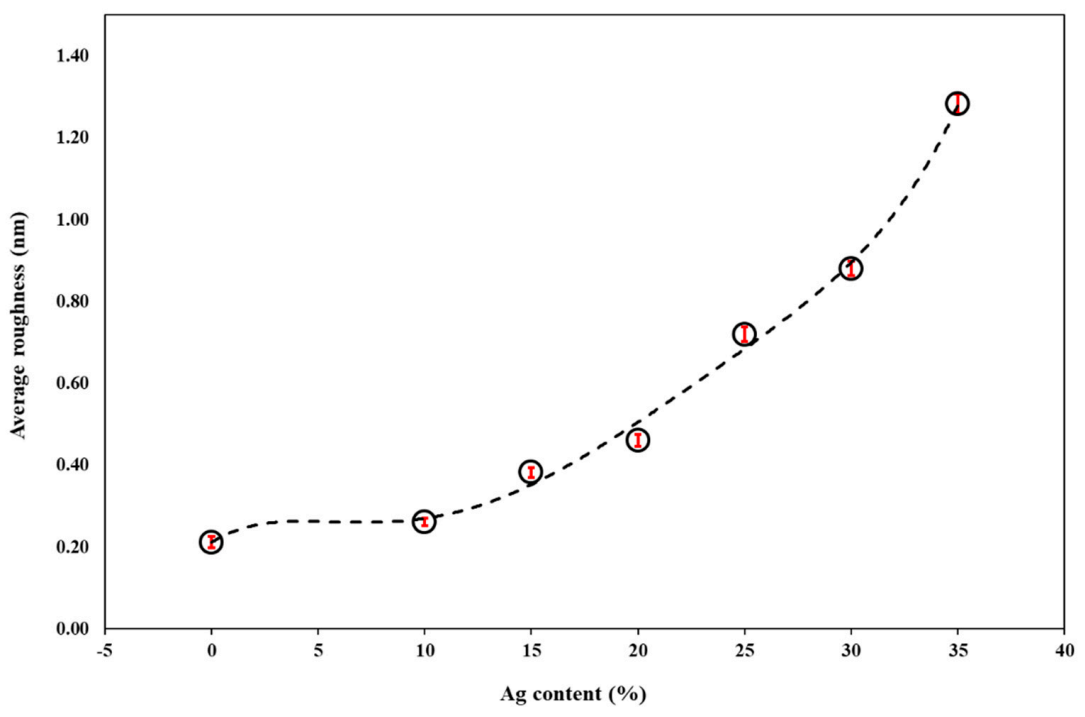

Figure 5. The average surface roughness of the Ti-Cu and $\mathrm{Ti}-\mathrm{Cu}-\mathrm{Ag}$ thin films as a function of the Ag content. 


\subsection{Mechanical Properties}

Thin films for the biomedical applications must have a high mechanical stability to insure their durability in service. The elastic modulus (E) and hardness $(\mathrm{H})$ of Ti-Cu-Ag thin films as a function of the Ag content are shown in Figure 6. The highest $\mathrm{E}$ and $\mathrm{H}$ values of $124.50 \mathrm{GPa}$ and $7.85 \mathrm{GPa}$, respectively, exhibit the $\mathrm{Ag}$ free Ti-Cu thin film. There is a slight decrease in both modulus (118.6 GPa) and hardness $(7 \mathrm{GPa})$ with the addition of silver into the Ti-Cu thin films. With the first addition of 10 at. $\% \mathrm{Ag}$, it shows $5 \%$ decrease in modulus and $10 \%$ decrease in hardness. The phase changes from amorphous to partially crystalline at 25 at.\% Ag and changes to completely crystalline with 35 at. $\%$ Ag, which causes the decrease in mechanical properties. At threshold phase change point of 25 at. $\%$ $\mathrm{Ag}$, there is a decrease of $10 \%$ in modulus and $18 \%$ in hardness which is almost two times lower than controlled sample. With the further addition of Ag into the Ti-Cu thin films, both modulus and hardness continuously decrease to the lowest values of $105.5 \mathrm{GPa}$ and $6 \mathrm{GPa}$ for $\mathrm{E}$ and $\mathrm{H}$, respectively, at 35 at.\% of $\mathrm{Ag}$ in the Ti-Cu-Ag thin films. The percentage decrease in modulus is $15.6 \%$ and hardness is $23.5 \%$ for 35 at. $\%$ Ag as compared to the controlled sample. Although the nanocrystalline materials are commonly harder and stiffer due to grain boundary-related hardening [54,55], the decrease of $\mathrm{E}$ and $\mathrm{H}$ of the Ti-Cu-Ag thin films is dominated by the effect of the addition of soft $\mathrm{Ag}$ atoms into the thin films and may even be intensified by softening due to rotation and/or sliding of crystallites with sub-critical size [56,57].

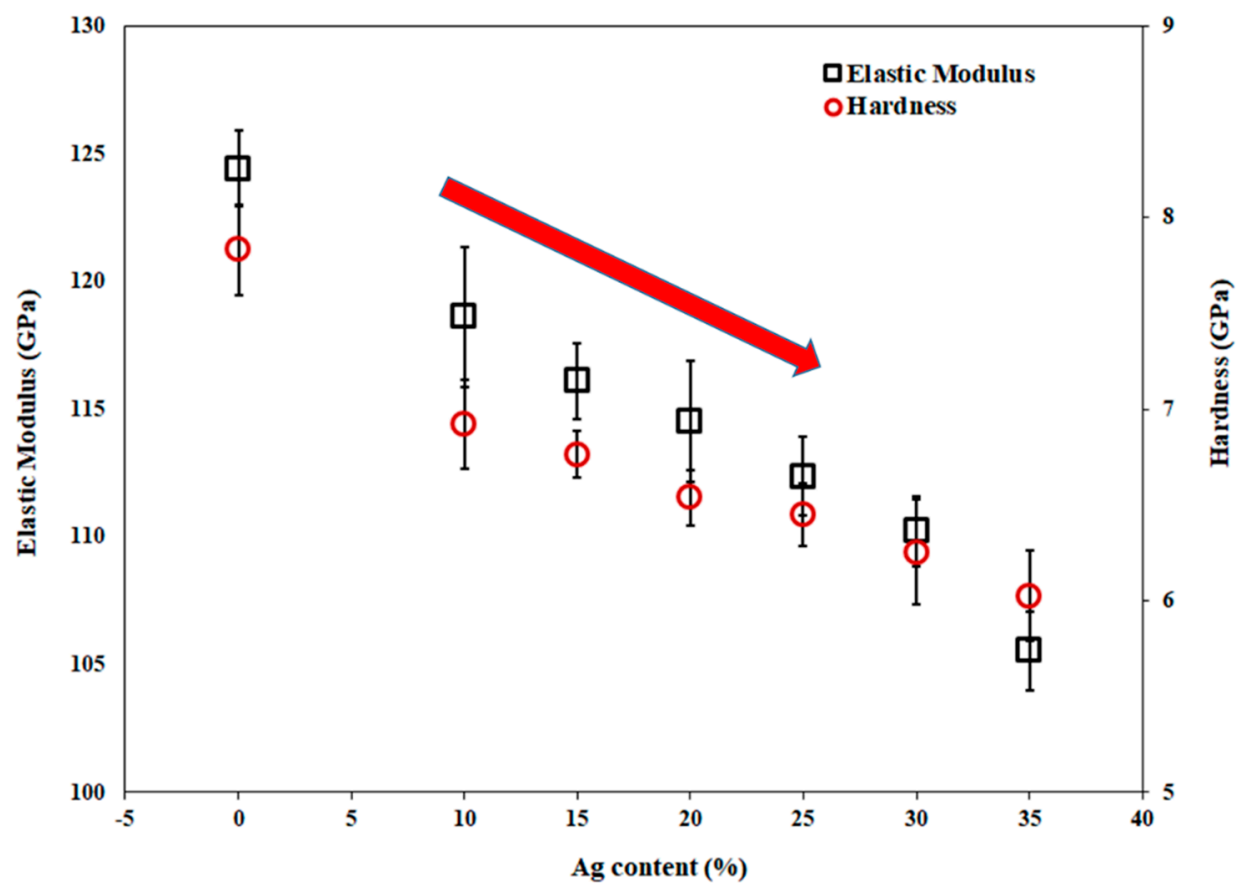

Figure 6. Elastic modulus and hardness of the Ti-Cu and Ti-Cu-Ag thin films as a function of the Ag content.

\subsection{Scratch Test}

The scratches on the thin film surfaces were observed with an optical profilometer and images at incident of the first failure (LC1) are shown in Figure 7. The first failure in all the thin films was semi-circular rings due to buckling inside the scratch track. The chipping of the films (LC2) shows the first delamination in the scratch track. Finally, the complete delamination of the thin film from the substrate occurred and is represented in the images as failure at LC3. 

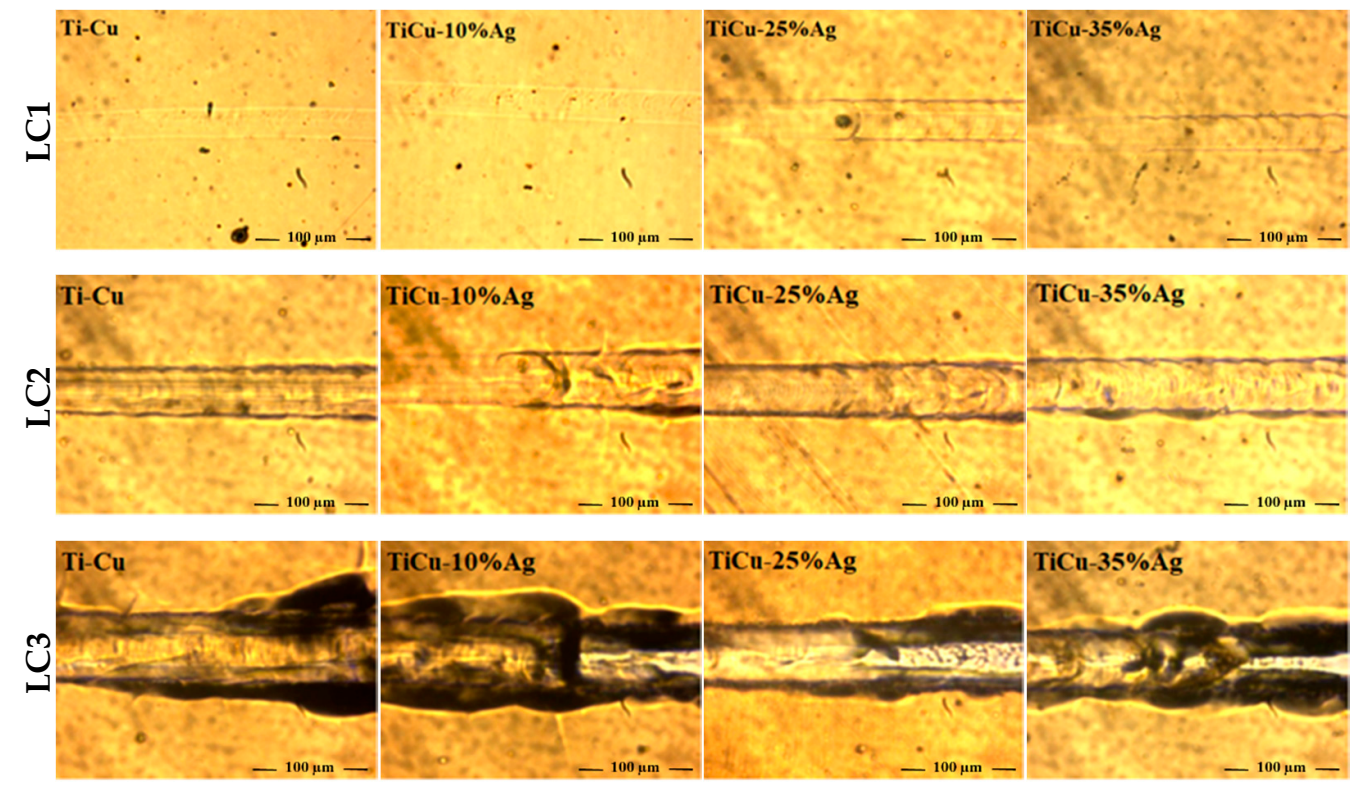

Figure 7. Representation of first failure LC1, second failure LC2, and complete delamination LC3 for the $\mathrm{TiCu}$ and $\mathrm{TiCuAg}$ thin films (scratch direction from left to right).

Scratch adhesion test confirms that produced thin films have good adhesion with the substrate. All the critical loads as a function of silver content in the Ti-Cu thin films are represented in the Figure 8. The critical load LC1 increases with the significant increase in silver content up to 20-25 at.\% and decreases for higher silver content. The silver containing thin films show significantly higher LC2 and LC3 values as compared to TiCu. The complete delamination of the thin films at higher critical load $(20-25 \mathrm{~N})$ reflects good adhesion with the substrate. The increase of critical load for increasing silver content is probably associated to the increase of ductility associated to the reduction of hardness for higher silver content [58,59].

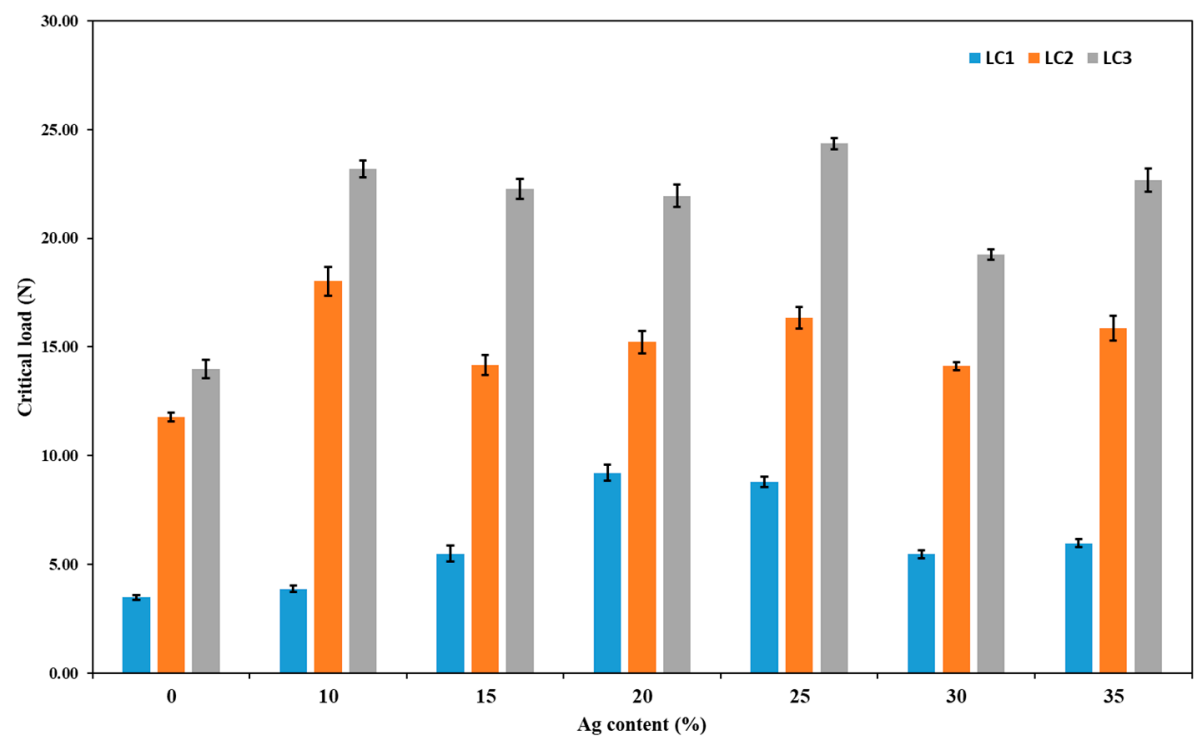

Figure 8. Critical load (LC1, LC2, and LC3) as a function of Ag content in the TiCu thin films. 


\subsection{Residual Stress Measurement}

The relaxation strain for the Ti-Cu and Ti-Cu-Ag thin films determined by the FIB-DIC method is shown in Figure 9. It represents a measure of the variation of the residual stress state induced during processing and as a consequence of the thermal expansion mismatch of a thin film and a substrate across the thin film thickness. The relaxation strain for the Ti$\mathrm{Cu}$ thin films shows positive and constant values throughout the entire thin film thickness, which corresponds to a steady compressive residual stress state in the thin films. All the $\mathrm{Ag}$-containing Ti-Cu-Ag thin films show negative relaxation strain values increasing from the thin film surfaces towards the thin film/substrate interface, which reflects a gradient in the tensile residual stress in the thin films. The development of the tensile stress state is obviously an effect related to the Ag addition, which correlates well with the decrease of hardness as the tensile residual stress in the thin films, together with the presence of Ag atoms, allows for more pronounced plastic deformation during nanoindentation.

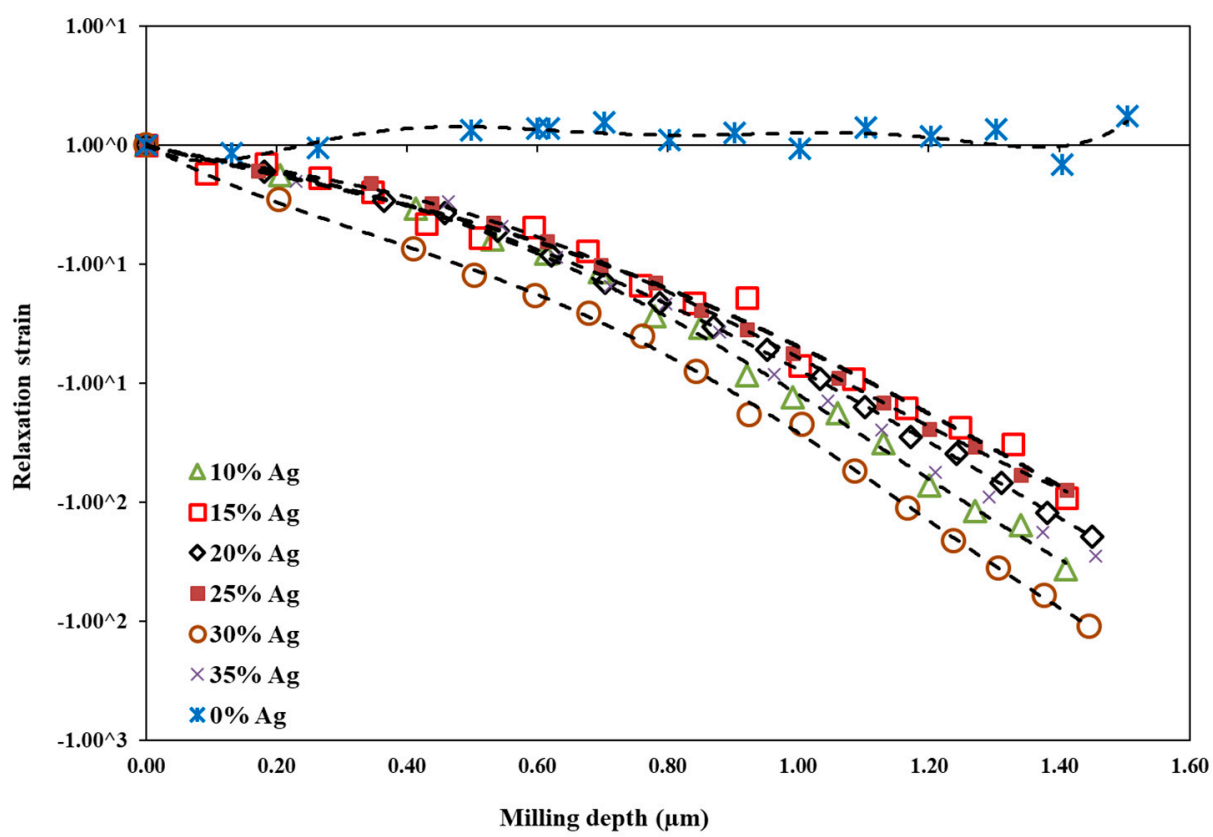

Figure 9. The relaxation strain determined by the focused ion beam and digital image correlation (FIB-DIC) method for Ti-Cu and Ti-Cu-Ag thin films with a various Ag content as a function of the milling depth.

Besides the absolute values, the slope of individual curves also gives us information about stress development in the thin films. The relaxation strain of the Ti-Cu-Ag thin film with 30 at.\% of $\mathrm{Ag}$ reveals a larger slope of the curve compared to other Ti-Cu-Ag thin films, which indicates a greater residual stress gradient in the thin film, which is likely associated with the polycrystalline nature of the thin film microstructure. In fact, larger tensile stress developed in the thin films deposited under identical process conditions but different crystallite sizes is given by the interaction of surface atoms across individual growing islands in the initial growth stages of polycrystalline materials and reduction of the surface area when adjacent growing islands form the grain boundaries [60]. Another important contribution to the tensile stress, which may be more significant than grain boundaries effects, is an increasing thermal expansion mismatch strain between the high Ag-containing thin films and the Si substrate, especially for the Ti-Cu-Ag thin film with the Ag content higher than 25 at.\% [61].

A comparison of average residual stress determined by using the FIB-DIC method and from the substrate curvature measurements is given in Figure 10. The residual stress obtained from both techniques shows a similar trend, with a clear transition from compressive to tensile stress in the thin films after the addition of silver. The Ti-Cu thin film exhibits 
compressive residual stress of $-36.5 \mathrm{MPa}$ and tensile stresses ranging from $228.5-314 \mathrm{MPa}$ developed in the thin films after the addition of silver from 10-35 at.\%. It is noteworthy that the values calculated by FIB-DIC are roughly 35\% higher than the values obtained by the substrate curvature method according to the Stoney's equation. This difference in the stress values determined from those two methods was already observed in our recent work and related to the difference of the representative volume element (RVE) in the two cases [48]. The curvature method takes into consideration the whole volume of the sample which can also include the stress relaxation effects associated with the microdefects and interfaces. On the other hand, FIB-DIC measures only a few cubic micrometers of the material that does not consider relaxation effects related to micro-cracks. Another important point to consider is that the wafer curvature method only takes into consideration the biaxial elastic modulus of the substrate, while the FIB-DIC method uses both the elastic modulus and the Poisson's ratio of the thin film and substrate for calculating the residual stress.

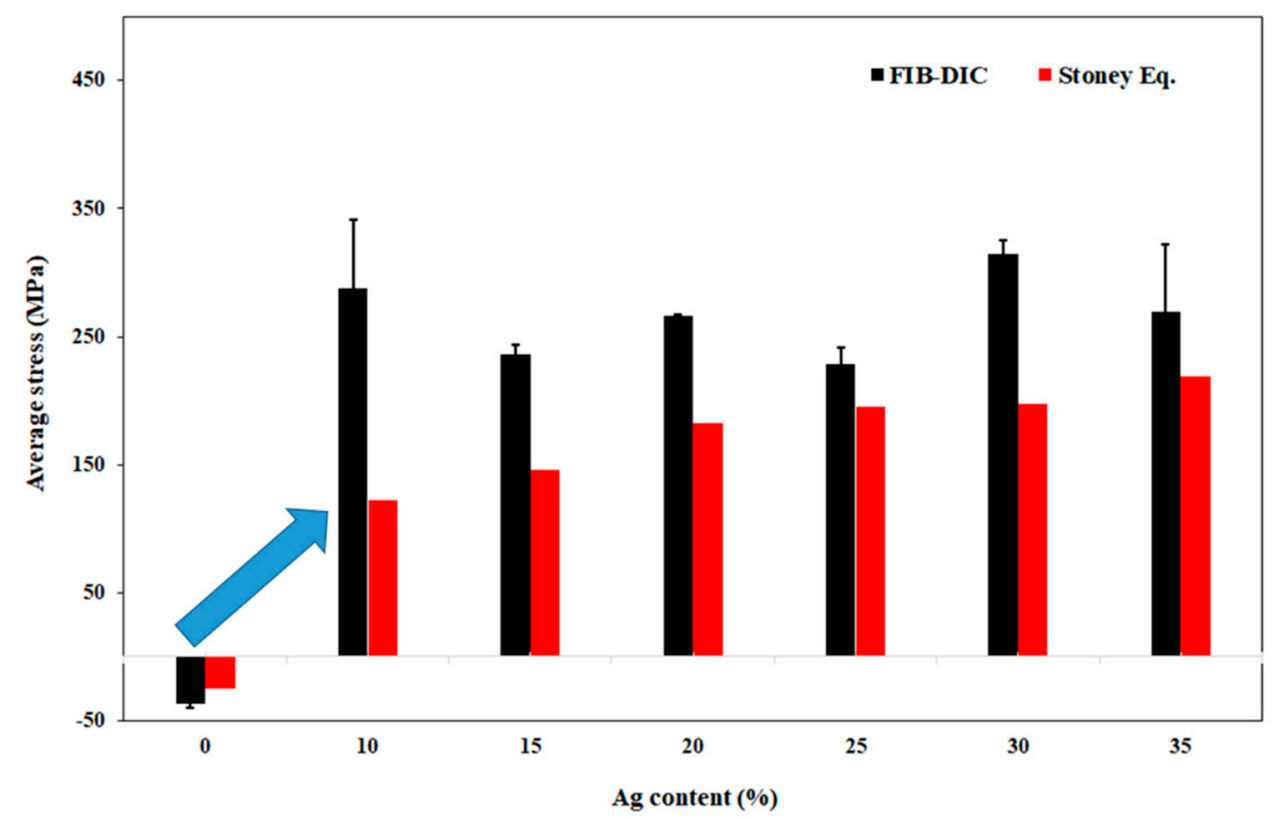

Figure 10. Average residual stress determined by the FIB-DIC method and from the substrate curvature measurements according to the Stoney's equation as a function of the Ag content in the Ti-Cu-Ag thin films.

In summary, the microstructural and nanomechanical characterization activities show a remarkable effect of silver addition on Ti-Cu-Ag co-sputtered thin films, where a transition from amorphous to crystalline and a more significant decrease of the mechanical properties are observed for $\mathrm{Ag}$ addition above 25 at.\%.

The present study, therefore, suggests that $\mathrm{Ti}_{35.5}-\mathrm{Cu}_{39.5}-\mathrm{Ag}_{25}$ thin film, with increased adhesion, sufficiently good hardness, and partially crystalline structure, can be considered as the optimal composition out of produced thin films. The proposed configuration, therefore, could be a suitable candidate for the evaluation of biocompatibility, antibacterial, and antiviral properties of the coatings, which will be the focus of the next work by the authors.

\section{Conclusions}

The binary Ti-Cu and ternary Ti-Cu-Ag thin films were deposited by PVD magnetron co-sputtering using a multi-target reactor. The purpose of this study is to understand the influence of Ag on the mechanical and structural properties of the thin films. All the thin films were homogenously thick and very smooth, with a maximum average roughness of $1.2 \mathrm{~nm}$. With regards to the silver content, thin films showed amorphous structure up to 
20 at. $\%$ of Ag that changed to partially crystalline at 25 at. $\%$ and then completely crystalline at higher Ag content in the thin film. The addition of silver content contributed to a significant increase of the thin film adhesion, but reduced both elastic modulus from 124.5 to $105.5 \mathrm{GPa}$ and hardness from 7.8 to $6 \mathrm{GPa}$. Ti-Cu thin films showed compressive residual stress and changed to completely tensile stresses with the addition of silver in the thin films. Based on the multi-technique characterization, it can be concluded that a suggested Ag composition of about 25 at.\% exists to find the optimal mechanical properties of Ti$\mathrm{Cu}$-Ag sputtered thin films (i.e., improved adhesion and sufficiently good hardness), still maintaining the potential of improving antibacterial properties thanks to silver addition and very small average surface roughness. Further work will focus on the optimization of the Ti-Cu-Ag composition and structure in order to investigate the biocompatibility and antibacterial (or even antiviral) properties of the thin films.

Author Contributions: S.R. performed the experiments, undertook the analysis, and wrote the manuscript. M.Z.M. performed residual stress measurements using FIB-DIC method, critically analyzed data and draw conclusion. R.D., M.S., and E.B. contributed to the analysis and supervised the progress of the research. All authors have read and agreed to the published version of the manuscript.

Funding: The authors gratefully acknowledge partial financial support from the European Commission, European project Oyster, grant agreement no. 760827.

Informed Consent Statement: Not applicable.

Data Availability Statement: The data presented in this study are available on request from the corresponding author.

Acknowledgments: The authors would like to thank the researchers of the Montanuniversität Leoben, Department of Materials Science (https://materials.unileoben.ac.at) and specifically to Velislava Terziyska for her assistance in the production of thin films. All the structural and mechanical characterization activities were carried out at the "Inter-Departmental Laboratory of Electron Microscopy" (LIME), University of ROMA TRE (http:/ / www.lime.uniroma3.it).

Conflicts of Interest: The authors declare no conflict of interest.

\section{References}

1. Niinomi, M.; Nakai, M.; Hieda, J. Development of new metallic alloys for biomedical applications. Acta Biomater. 2012, 8, 3888-3903. [CrossRef]

2. $\quad$ Breme, H.; Biehl, V.; Reger, N.; Gawalt, E. Metallic biomaterials: Introduction. In Handbook of Biomaterial Properties, 2nd ed.; Springer: New York, NY, USA, 2016; pp. 151-158.

3. Chen, Q.; Thouas, G.A. Metallic implant biomaterials. Mater. Sci. Eng. R Rep. 2015, 87, 1-57. [CrossRef]

4. Biehl, V.; Wack, T.; Winter, S.; Seyfert, U.T.; Breme, J. Evaluation of the haemocompatibility of titanium based biomaterials. Biomol. Eng. 2002, 19, 97-101. [CrossRef]

5. Okazaki, Y.; Gotoh, E. Metal release from stainless steel, Co-Cr-Mo-Ni-Fe and Ni-Ti alloys in vascular implants. Corros. Sci. 2008, 50, 3429-3438. [CrossRef]

6. Avila, I.; Pantchev, K.; Holopainen, J.; Ritala, M.; Tuukkanen, J. Adhesion and mechanical properties of nanocrystalline hydroxyapatite coating obtained by conversion of atomic layer-deposited calcium carbonate on titanium substrate. J. Mater. Sci. Mater. Electron. 2018, 29, 111. [CrossRef]

7. Espallargas, N.; Torres, C.; Muñoz, A. A metal ion release study of CoCrMo exposed to corrosion and tribocorrosion conditions in simulated body fluids. Wear 2015, 332-333, 669-678. [CrossRef]

8. Campoccia, D.; Montanaro, L.; Arciola, C.R. A review of the biomaterials technologies for infection-resistant surfaces. Biomaterials 2013, 34, 8533-8554. [CrossRef]

9. Chouirfa, H.; Bouloussa, H.; Migonney, V.; Falentin-Daudré, C. Review of titanium surface modification techniques and coatings for antibacterial applications. Acta Biomater. 2019, 83, 37-54. [CrossRef]

10. Bemporad, E.; Sebastiani, M.; Pecchio, C.; De Rossi, S. High thickness Ti/TiN multilayer thin coatings for wear resistant applications. Surf. Coat. Technol. 2006, 201, 2155-2165. [CrossRef]

11. Balaceanu, M.; Petreus, T.; Braic, V.; Zoita, C.; Vladescu, A.; Cotrutz, C.; Braic, M. Characterization of Zr-based hard coatings for medical implant applications. Surf. Coat. Technol. 2010, 204, 2046-2050. [CrossRef]

12. Khan, M.M.; Deen, K.; Haider, W. Combinatorial development and assessment of a Zr-based metallic glass for prospective biomedical applications. J. Non-Cryst. Solids 2019, 523, 119544. [CrossRef] 
13. Major, L.; Krawiec, H.; Lackner, J.; Dyner, M.; Grysakowski, B.; Major, B. Nanoscale characterization of corrosion mechanisms in advanced $\mathrm{Zr} / \mathrm{ZrxN}$ and $\mathrm{Zr} / \mathrm{ZrxN}+\mathrm{a}-\mathrm{C}: \mathrm{H}$ nano-multilayer coatings for medical tools. Mater. Charact. 2020, 168, 110565. [CrossRef]

14. Shypylenko, A.; Pshyk, A.V.; Grześkowiak, B.; Medjanik, K.; Peplinska, B.; Oyoshi, K.; Pogrebnjak, A.; Jurga, S.; Coy, E. Effect of ion implantation on the physical and mechanical properties of Ti-Si-N multifunctional coatings for biomedical applications. Mater. Des. 2016, 110, 821-829. [CrossRef]

15. Shtansky, D.; Gloushankova, N.; Sheveiko, A.; Kharitonova, M.; Moizhess, T.; Levashov, E.; Rossi, F. Design, characterization and testing of Ti-based multicomponent coatings for load-bearing medical applications. Biomaterials 2005, 26, 2909-2924. [CrossRef]

16. Apreutesei, M.; Steyer, P.; Joly-Pottuz, L.; Billard, A.; Qiao, J.; Cardinal, S.; Sanchette, F.; Pelletier, J.-M.; Esnouf, C. Microstructural, thermal and mechanical behavior of co-sputtered binary Zr-Cu thin film metallic glasses. Thin Solid Films 2014, 561, 53-59. [CrossRef]

17. Lopes, C.; Gonçalves, C.; Borges, J.N.P.; Polcar, T.; Rodrigues, M.S.; Barradas, N.; Alves, E.; Le Bourhis, E.; Couto, F.; Macedo, F.; et al. Evolution of the functional properties of titanium-silver thin films for biomedical applications: Influence of in-vacuum annealing. Surf. Coat. Technol. 2015, 261, 262-271. [CrossRef]

18. Lopes, C.; Gabor, C.; Cristea, D.; Costa, R.; Domingues, R.; Rodrigues, M.; Borges, J.; Alves, E.; Barradas, N.; Munteanu, D.; et al. Evolution of the mechanical properties of Ti-based intermetallic thin films doped with different metals to be used as biomedical devices. Appl. Surf. Sci. 2020, 505, 144617. [CrossRef]

19. Cai, C.-N.; Zhang, C.; Sun, Y.-S.; Huang, H.-H.; Yang, C.; Liu, L. ZrCuFeAlAg thin film metallic glass for potential dental applications. Intermetallics 2017, 86, 80-87. [CrossRef]

20. Lou, B.-S.; Yang, Y.-C.; Lee, J.-W.; Chen, L.-T. Biocompatibility and mechanical property evaluation of Zr-Ti-Fe based ternary thin film metallic glasses. Surf. Coat. Technol. 2017, 320, 512-519. [CrossRef]

21. Baptista, A.; Silva, F.J.G.; Porteiro, J.; Míguez, J.; Pinto, G.; Fernandes, L. On the Physical Vapour Deposition (PVD): Evolution of Magnetron Sputtering Processes for Industrial Applications. Procedia Manuf. 2018, 17, 746-757. [CrossRef]

22. Ng, C.-H.; Rao, J.; Nicholls, J. The role of PVD sputtered PTFE and $\mathrm{Al}_{2} \mathrm{O}_{3}$ thin films in the development of damage tolerant coating systems. J. Mater. Res. Technol. 2020, 9, 675-686. [CrossRef]

23. Alias, R.; Mahmoodian, R.; Hamdi, M. Development and characterization of a multilayer silver/silver-tantalum oxide thin film coating on stainless steel for biomedical applications. Int. J. Adhes. Adhes. 2019, 92, 89-98. [CrossRef]

24. Bahi, R.; Nouveau, C.; Beliardouh, N.E.; Ramoul, C.; Meddah, S.; Ghelloudj, O. Surface performances of Ti-6Al-4V substrates coated PVD multilayered films in biological environments. Surf. Coat. Technol. 2020, 385, 125412. [CrossRef]

25. Kawamura, M.; Zhang, Z.; Kiyono, R.; Abe, Y. Thermal stability and electrical properties of Ag-Ti films and Ti/Ag/Ti films prepared by sputtering. Vacuum 2013, 87, 222-226. [CrossRef]

26. Hsu, J.-H.; Larson, C.M.; Newkirk, J.W.; Brow, R.K.; Zhang, S.-H. The Corrosion Behavior of Ni 3 (Si,Nb) Alloys in Boiling 70 wt.\% Sulfuric Acid. J. Mater. Eng. Perform. 2016, 25, 510-517. [CrossRef]

27. Cheng, K.-F.; Yang, F.-C.; Wu, K.-H.; Liu, X.-M. Evaluation and efficacy of metal oxides in terms of antibacterial activity and toxic chemical degradation. Mater. Sci. Eng. C 2018, 93, 615-622. [CrossRef]

28. Saravanan, M.; Arokiyaraj, S.; Lakshmi, T.; Ad, P. Synthesis of silver nanoparticles from Phenerochaete chrysosporium (MTCC-787) and their antibacterial activity against human pathogenic bacteria. Microb. Pathog. 2018, 117, 68-72. [CrossRef]

29. Chernousova, S.; Epple, M. Silver as Antibacterial Agent: Ion, Nanoparticle, and Metal. Angew. Chem. Int. Ed. 2013, 52, 1636-1653. [CrossRef] [PubMed]

30. Feng, Q.L.; Wu, J.; Chen, G.Q.; Cui, F.Z.; Kim, T.N.; Kim, J.O. A mechanistic study of the antibacterial effect of silver ions on Escherichia coli and Staphylococcus aureus. J. Biomed. Mater. Res. 2000, 52, 662-668. [CrossRef]

31. Rai, M.; Yadav, A.; Gade, A. Silver nanoparticles as a new generation of antimicrobials. Biotechnol. Adv. 2009, 27, 76-83. [CrossRef]

32. Ewald, A.; Glückermann, S.K.; Thull, R.; Gbureck, U. Antimicrobial titanium/silver PVD coatings on titanium. Biomed. Eng. Online 2006, 5, 1-10. [CrossRef]

33. Bouala, G.N.; Etiemble, A.; Der Loughian, C.; Langlois, C.; Pierson, J.-F.; Steyer, P. Silver influence on the antibacterial activity of multi-functional Zr-Cu based thin film metallic glasses. Surf. Coat. Technol. 2018, 343, 108-114. [CrossRef]

34. Etiemble, A.; Der Loughian, C.; Apreutesei, M.; Langlois, C.; Cardinal, S.; Pelletier, J.-M.; Pierson, J.-F.; Steyer, P. Innovative $\mathrm{Zr}-\mathrm{Cu}-\mathrm{Ag}$ thin film metallic glass deposed by magnetron PVD sputtering for antibacterial applications. J. Alloys Compd. 2017, 707, 155-161. [CrossRef]

35. Takahashi, M.; Kikuchi, M.; Takada, Y. Corrosion behavior of Ti-Ag alloys used in dentistry in lactic acid solution. Met. Mater. Int. 2011, 17, 175-179. [CrossRef]

36. Shirai, T.; Tsuchiya, H.; Shimizu, T.; Ohtani, K.; Zen, Y.; Tomita, K. Prevention of pin tract infection with titanium-copper alloys. J. Biomed. Mater. Res. Part B Appl. Biomater. 2009, 91, 373-380. [CrossRef]

37. Zhang, E.; Zheng, L.; Liu, J.; Bai, B.; Liu, C. Influence of Cu content on the cell biocompatibility of Ti-Cu sintered alloys. Mater. Sci. Eng. C 2015, 46, 148-157. [CrossRef]

38. Aruoma, O.I.; Halliwell, B.; Gajewski, E.; Dizdaroglu, M. Copper-ion-dependent damage to the bases in DNA in the presence of hydrogen peroxide. Biochem. J. 1991, 273, 601-604. [CrossRef]

39. Banci, L.; Bertini, I.; Cantini, F.; Ciofi-Baffoni, S. Cellular copper distribution: A mechanistic systems biology approach. Cell. Mol. Life Sci. 2010, 67, 2563-2589. [CrossRef] 
40. Wojcieszak, D.; Kaczmarek, D.; Antosiak, A.; Mazur, M.; Rybak, Z.; Rusak, A.; Osekowska, M.; Poniedzialek, A.; Gamian, A.; Szponar, B. Influence of $\mathrm{Cu}-\mathrm{Ti}$ thin film surface properties on antimicrobial activity and viability of living cells. Mater. Sci. Eng. C 2015, 56, 48-56. [CrossRef]

41. Sun, Z.; Ostrikov, K. Future antiviral surfaces: Lessons from COVID-19 pandemic. Sustain. Mater. Technol. 2020, 25, e00203. [CrossRef]

42. Miyauchi, M.S.; Sunada, K.; Hashimoto, K. Antiviral Effect of Visible Light-Sensitive $\mathrm{Cu}_{\mathrm{x}} \mathrm{O} / \mathrm{TiO}_{2}$ Photocatalyst. Catalysts 2020, 10, 1093. [CrossRef]

43. Hutasoit, N.; Kennedy, B.; Hamilton, S.; Luttick, A.; Rashid, R.A.R.; Palanisamy, S. Sars-CoV-2 (COVID-19) inactivation capability of copper-coated touch surface fabricated by cold-spray technology. Manuf. Lett. 2020, 25, 93-97. [CrossRef] [PubMed]

44. Mughal, M.Z.; Lemoine, P.; Lubarsky, G.; Maguire, P. Protein adsorption on nano-patterned hydrogenated amorphous carbon model surfaces. Mater. Des. 2016, 97, 239-248. [CrossRef]

45. Ghidelli, M.; Sebastiani, M.; Collet, C.; Guillemet, R. Determination of the elastic moduli and residual stresses of freestanding Au-TiW bilayer thin films by nanoindentation. Mater. Des. 2016, 106, 436-445. [CrossRef]

46. Oliver, W.; Pharr, G. An improved technique for determining hardness and elastic modulus using load and displacement sensing indentation experiments. J. Mater. Res. 1992, 7, 1564-1583. [CrossRef]

47. Sebastiani, M.; Eberl, C.; Bemporad, E.; Pharr, G.M. Depth-resolved residual stress analysis of thin coatings by a new FIB-DIC method. Mater. Sci. Eng. A 2011, 528, 7901-7908. [CrossRef]

48. Sebastiani, M.; Rossi, E.; Zeeshan Mughal, M.; Benedetto, A.; Jacquet, P.; Salvati, E.; Korsunsky, A.M. Nano-Scale Residual Stress Profiling in Thin Multilayer Films with Non-Equibiaxial Stress State. Nanomaterials 2020, 10, 853. [CrossRef]

49. Salvati, E.; Romano-Brandt, L.; Mughal, M.Z.; Sebastiani, M.; Korsunsky, A.M. Generalised residual stress depth profiling at the nanoscale using focused ion beam milling. J. Mech. Phys. Solids 2019, 125, 488-501. [CrossRef]

50. Korsunsky, A.M.; Salvati, E.; Lunt, A.; Sui, T.; Mughal, M.; Daniel, R.; Keckes, J.; Bemporad, E.; Sebastiani, M. Nanoscale residual stress depth profiling by Focused Ion Beam milling and eigenstrain analysis. Mater. Des. 2018, 145, 55-64. [CrossRef]

51. MATLAB Central. Digital Image Correlation and Tracking. 2 July 2016. Available online: https://www.mathworks.com/ matlabcentral/ fileexchange/50994-digital-image-correlation-and-tracking (accessed on 28 January 2021).

52. Korsunsky, A.M.; Sebastiani, M.; Bemporad, E. Focused ion beam ring drilling for residual stress evaluation. Mater. Lett. 2009, 63, 1961-1963. [CrossRef]

53. Lemire, J.A.; Harrison, J.J.; Turner, R.J. Antimicrobial activity of metals: Mechanisms, molecular targets and applications. Nat. Rev. Microbiol. 2013, 11,371-384. [CrossRef]

54. Daniel, R.; Meindlhumer, M.; Baumegger, W.; Todt, J.; Zalesak, J.; Ziegelwanger, T.; Mitterer, C.; Keckes, J. Anisotropy of fracture toughness in nanostructured ceramics controlled by grain boundary design. Mater. Des. 2019, 161, 80-85. [CrossRef]

55. Dehm, G.; Balk, T.; Edongué, H.; Arzt, E. Small-scale plasticity in thin Cu and Al films. Microelectron. Eng. 2003, 70, 412-424. [CrossRef]

56. Liu, J.; Fan, X.; Zheng, W.; Singh, D.J.; Shi, Y. Nanocrystalline gold with small size: Inverse Hall-Petch between mixed regime and super-soft regime. Philos. Mag. 2020, 100, 2335-2351. [CrossRef]

57. Naik, S.N.; Walley, S.M. The Hall-Petch and inverse Hall-Petch relations and the hardness of nanocrystalline metals. J. Mater. Sci. 2020, 55, 2661-2681. [CrossRef]

58. Renzelli, M.; Mughal, M.Z.; Sebastiani, M.; Bemporad, E. Design, fabrication and characterization of multilayer Cr-CrN thin coatings with tailored residual stress profiles. Mater. Des. 2016, 112, 162-171. [CrossRef]

59. Sebastiani, M.; Bolelli, G.; Lusvarghi, L.; Bandyopadhyay, P.; Bemporad, E. High resolution residual stress measurement on amorphous and crystalline plasma-sprayed single-splats. Surf. Coat. Technol. 2012, 206, 4872-4880. [CrossRef]

60. Doljack, F.; Hoffman, R. The origins of stress in thin nickel films. Thin Solid Films 1972, 12, 71-74. [CrossRef]

61. Daniel, R.; Martinschitz, K.; Keckes, J.; Mitterer, C. The origin of stresses in magnetron-sputtered thin films with zone T structures. Acta Mater. 2010, 58, 2621-2633. [CrossRef] 